\title{
РОЛЬ БІОХІМІЧНИХ ПОРУШЕНЬ У РОЗВИТКУ ЕТАНОЛОВИХ ФІБРОЗУ І ЦИРОЗУ ПЕЧІНКИ У ВИСОКО- ТА НИЗЬКОЕМОЦІЙНИХ ЩУРІВ
}

\begin{abstract}
Вступ. Надмірне вживання алкоголю є поширеним соціальним лихом, що спричинює незворотні зміни в організмі.

Мета дослідження - оцінити стан про- й антиоксидантної системи у крові та гомогенаті серця високо- і низькоемоційних (BE, HE) щурів-самців при етанолових фріброзі та цирозі печінки.

Методи дослідження. Досліди виконано на 96 ВЕ і НЕ безпородних щурах-самцях віком 5,5-6 місяців. Тварин поділили на 3 групи: контрольна (К); етаноловий фріброз (ЕФ); етаноловий цироз печінки (ЕЦ). Емоційність визначали за методикою "відкрите поле". У сироватці крові (сир) та гомогенаті серця (гом) визначали активність супероксиддисмутази (СОД), каталази (Кат), вміст дієнових (ДК), трієнових (ТК) кон'югатів, шифрорових основ (ШО), ТБК-активних продуктів (ТБК-ап), у сироватці крові - пероксидазну активність крові (ПАК), вміст церулоплазміну (ЦП).

Результати й обговорення. У К у ВЕ тварин, порівняно з НЕ, був меншим вміст ДК, ТК, ТБК-аП, більшим - вміст ШО. При ЕФ та ЕЦ усі показники у ВЕ і НЕ щурів зросли і були вищими у ВЕ тварин. У К у ВЕ щурів ОМП у сир ВЕ тварин). У сир ВЕ щурів ОМП шими у ВЕ і НЕ тварин, а в гом - більшими в НЕ щурів. При ЕЦ, порівняно з ЕФ, ОМП сир HЕ тварин. У К активність СОД була вищою в НЕ щурів. При ЕФ вона зросла, більще у ВЕ тварин, але залишалася вищою в НЕ щурів. При ЕЦ зросла більше у ВЕ тварин і була вищою в гом. При ЕЦ, порівняно з ЕФ, активність СОД була більшою. Активність Кат у сир у К була вищою в НЕ щурів. При ЕФ вона збільшилась $і$ була вищою у ВЕ тварин. При ЕЦ зростала більшою мірою у ВЕ щурів і не залежала від емоційності. При ЕЦ, порівняно з ЕФ, активність Кат була більшою. Вміст ЦП у сир був вищим у ВЕ тварин. При ЕФ та ЕЦ він зріс, більше у НЕ щурів. Різниці у вмісті ЦП при ЕФ та ЕЦ у ВЕ тварин не спостерігали, в НЕ щурів вищі значення відзначали при ЕЦ. При ЕФ у ВЕ тварин вміст ЦП залишався більшим. У К ПАК була вищою в НЕ щурів; зросла при ЕФ та ЕЦ (більшою мірою). При ЕЦ ПАК була вищою у ВЕ тварин.

Висновки. Етанолові фріброз і цироз печінки у щурів викликають ушкодження організму за оксидаційним механізмом. Інтенсифрікація ПОл більш виражена при цирозі у сироватці крові та гомогенаті серця високоемоційних тварин.
\end{abstract}

КЛЮчОВІ СЛОВА: етанол; фріброз печінки; цироз печінки; високо- і низькоемоційні щури-самці; кров; серце.

ВСТУП. В останні роки у світі інтенсивно вивчають неалкогольне ушкодження печінки й ускладнення, пов'язані з ним. Незважаючи на це, проблема алкогольного ушкодження залишається актуальною [1]. Алкогольна хвороба печінки починається зі стеатозу і прогресує до цирозу. Хронічне вживання алкоголю призводить до вірогідного зростання ризику розвитку алкогольного цирозу [2]. При етаноловому ушкодженні печінки в патологічний процес залучаються всі органи та системи організму, зокрема серце, мозок, нирки. Надмірне вживання алкоголю асоціюється 3 підвищеним ризиком розвитку серцево-судинних захворювань, таких, як алкогольна кардіоміопатія, артеріальна гіпертензія, с О. А. Костюк, О. В. Денефіль, 2020. аритмії передсердь, інсульт [3, 4]. До патогенезу серцево-судинних захворювань у пацієнтів 3 алкогольною хворобою печінки може бути залучений окиснювальний стрес [5].

У популяції є люди з різною реактивністю, що залежить як від швидкості метаболічних процесів, так і від психологічних особливостей особи. Зв'язок між психікою та соматикою $€$ взаємозалежним [6].

Активація процесів вільнорадикального окиснення ліпідів $€$ неспецисрічною реакцією та відбувається при будь-якій патології. Надмірне накопичення продуктів пероксидного окиснення ліпідів (ПОЛ) спричинює ушкодження мембран, сприяє ушкодженню протеїнів, деградації сполучної тканини [7]. 
Мета дослідження - оцінити стан про- й антиоксидантної системи у крові та гомогенаті серця високо- і низькоемоційних (BE, HЕ) щурів-самців при етанолових фріброзі та цирозі печінки.

МЕТОДИ ДОСЛІДЖЕННЯ. Досліди виконано на 96 BE і НЕ безпородних щурах-самцях віком 5,5-6 місяців. Тварин поділили на 3 групи: контрольна (К); етаноловий фріброз (ЕФ); етаноловий цироз печінки (ЕЦ).

Тварин контрольної групи утримували на стандартному харчовому раціоні віварію протягом усього періоду моделювання в інших групах ЕФ і ЕЦ $з$ вільним доступом до води.

Для моделювання ЕФ та ЕЦ проводили адаптацію до алкоголю: в 1-й тиждень щури отримували в поїлках замість води $5 \%$ розчин етанолу, розбавлений $5 \%$ розчином глюкози, на 2-й тиждень - $15 \%$ розчин етанолу, розбавлений глюкозою, без обмежень в їжі. Починаючи з 3-го тижня, була інтенсивна алкоголізація $96 \%$ розчином етанолу на шматочку білого хліба протягом 12 тижнів - 14 г/кг (для ЕФ) та 18 г/кг маси (для ЕЦ) без обмежень у воді. Двічі на тиждень тваринам давали овес. Усім щурам проводили гістологічне дослідження печінки для підтвердження змодельованої патології $[8,9]$.

Емоційність щурів визначали за методикою "відкрите поле", яка дозволяє оцінити фрізіологічну реакцію на нову обстановку, надає індрормацію про рухову, дослідницьку та емоційну активність тварин [10]. До високоемоційних щурів ми віднесли тих, в яких були висока горизонтальна і вертикальна активність, інтенсивне дослідження отворів у днищі тестової камери (нірок), нечасті завмирання, і навпаки, до низькоемоційних - тих, в яких були низька рухова активність, велика кількість завмирань і збільшення їх тривалості, уникання тваринами центральних квадратів, що свідчить про високий рівень тривожності.

Усі досліди виконували в першій половині дня в спеціально відведеному приміщенні при температурі $18-22{ }^{\circ} \mathrm{C}$, відносній вологості 40 $60 \%$ і освітленості 250 лк. Експерименти проведено з дотриманням норм Європейської конвенції про захист хребетних тварин, що використовуються для дослідних та інших наукових цілей (Страсбург, 18.03.1986 р.), ухвали Першого національного конгресу з біоетики (Київ, 2001) і наказу МОЗ України від 23.09.2009 р. № 690.

Евтаназію щурів проводили шляхом тотального кровопускання із серця після попереднього використання тіопентал-натрієвого наркозу (60 мг $\cdot \mathrm{K}^{-1}$ маси тіла тварини внутрішньочеревно). За загальноприйнятими методиками у си- роватці крові (сир) та гомогенаті серця (гом) визначали активність супероксиддисмутази (СОД) [11], каталази (Кат) [12], вміст дієнових кон'югатів (ДК), трієнових кон'югатів (ТК), шифффових основ (ШО) [13], ТБК-активних продуктів (ТБК-ап) [14, 15], окисномодисрікованих протеїнів $\left(\mathrm{OM} \Pi_{370}\right.$, ОМП $\left.{ }_{430}\right)$ [16], у сироватці крові - концентрацію церулоплазміну (ЦП) [17], пероксидазну активність крові (ПАК) [18].

Статистичну обробку цисррових даних виконано за допомогою програмного забезпечення Excel ("Microsoft", США) i STATISTICA 6.0 ("Statsoft", США). Достовірність різниці значень між незалежними кількісними величинами визначали при нормальному розподілі за критерієм Стьюдента, в інших випадках - за допомогою непараметричних методів. Відмінності між величинами вважали достовірними за вірогідності альтернативної гіпотези не менше ніж 0,95 [19].

РЕЗУЛЬТАТИЙОБГОВОРЕННЯ. У КОНТРОЛЬних ВЕ щурів, порівняно з НЕ, у сироватці крові та гомогенаті серця виявлено менші значення ДК (на 32,6 \%, p<0,001; на 31,4\%, p<0,001), ТК (на 35,1\%, p<0,001; на 38,8\%, $p<0,001$ ), ТБК-ап (на 27,7\%, p<0,001; на 29,5\%, p<0,001) та більший показник ШО (на 19,3 \%, p<0,001; на $18,0 \%, p<0,001)$ (табл. 1, 2). Враховуючи те, що у ВЕ тварин вище значення ШО, можна думати, що в них більша потужність антиоксидантної системи, що забезпечує швидке знешкодження проміжних продуктів ПОЛ з активним утворенням кінцевих метаболітів.

При аналізі змін показників ПОЛ при ЕФ, порівняно з К, ми відмітили їх достовірне збільшення у крові й гомогенаті серця всіх тварин. Так, у ВЕ щурів підвищення значень було таким: ДК $(p<0,001)$, ТК - відповідно, на $85 \%(p<0,001)$ i $97,3 \%(p<0,001)$, ТБК-ап - на 82,4\% $(p<0,001)$ й у 2,2 раза $(p<0,001)$, ШО - на 49,8 $\%(p<0,001)$ та $41,7 \%$ ( $<<0,001)$. У НЕ тварин збільшення показників було таким: ДК - на 30,5 \% $(\mathrm{p}<0,001)$ і 30,5\% $(p<0,001)$, TK - на 35,7 \% $(p<0,001)$ та $35,8 \%(p<0,001)$, ТБК-ап - на 37,8 \% $(p<0,001)$ i $61,4 \%(p<0,001)$, шО - на 61,5\% $(p<0,001)$ та $58,4 \%(p<0,001)$. Незважаючи на те, що у $\mathrm{K}$ значення ДК, ТК і ТБК-ап були вищими в НЕ Тварин, при фріброзі показники ДК, ТК, ТБК-ап, а також ШО були достовірно більшими у ВЕ щурів. Отримані результати вказують на більше накопичення продуктів ПОЛ в організмі ВЕ щурів.

При аналізі змін показників ПОЛ при ЕЦ, порівняно з К, ми також відмітили їх достовірне збільшення у крові й гомогенаті серця. У ВЕ щурів підвищення значень було таким: ДК сир $і$ д $\mathrm{K}_{\text {гом }}-$ у 2,1 раза ( $<<0,001)$, ТК - відповідно, у 2,2 раза 
Таблиця 1 - Зміни дієнових і трієнових кон'югатів у сироватці крові та гомогенаті серця високо- і низькоемоційних щурів, викликані етанолом (M $\pm m, n=12)$

\begin{tabular}{|c|c|c|c|c|}
\hline \multirow{3}{*}{ Група } & \multicolumn{4}{|c|}{ "Показник } \\
\hline & \multicolumn{2}{|c|}{ ДК } & \multicolumn{2}{|c|}{ TK } \\
\hline & $\begin{array}{c}\text { сироватка крові, } \\
\text { ум. од. } \cdot \text { мл }^{-1}\end{array}$ & $\begin{array}{c}\text { гомогенат серця, } \\
\text { ум. од. } \text { г }^{-1}\end{array}$ & $\begin{array}{c}\text { сироватка крові, } \\
\text { ум. од. } \text { мл }^{-1}\end{array}$ & $\begin{array}{c}\text { гомогенат серця, } \\
\text { ум. од. } \cdot \mathrm{r}^{-1} \\
\end{array}$ \\
\hline \multicolumn{5}{|c|}{ ВЕ тварини } \\
\hline Контрольна & $2,867 \pm 0,005$ & $2,765 \pm 0,005$ & $2,665 \pm 0,005$ & $2,390 \pm 0,016$ \\
\hline Етаноловий фріброз & $5,030 \pm 0,014^{*}$ & $4,888 \pm 0,020^{\star}$ & $4,930 \pm 0,012^{*}$ & $4,716 \pm 0,031^{*}$ \\
\hline Етаноловий цироз & $5,937 \pm 0,007^{\star, \star \star}$ & $5,850 \pm 0,006^{\star, \star \star}$ & $5,787 \pm 0,011^{\star, \star \star}$ & $5,320 \pm 0,019^{\star, \star *}$ \\
\hline \multicolumn{5}{|c|}{ НЕ тварини } \\
\hline Контрольна & $3,801 \pm 0,022^{\#}$ & $3,634 \pm 0,006^{\#}$ & $3,600 \pm 0,022^{\#}$ & $3,317 \pm 0,016^{\#}$ \\
\hline Етаноловий фріброз & $4,961 \pm 0,007^{*, \#}$ & $4,744 \pm 0,007^{\star, \#}$ & $4,885 \pm 0,013^{\star, \#}$ & $4,504 \pm 0,015^{\star, \#}$ \\
\hline Етаноловий цироз & $5,701 \pm 0,014^{\star, \#, \star \star}$ & $5,551 \pm 0,020^{\star, \#, \star \star}$ & $5,551 \pm 0,021^{\star, \#, \star \star}$ & $5,139 \pm 0,015^{\star, \#, \star \star}$ \\
\hline
\end{tabular}

Примітка. Тут і в таблицях 2-5: * - показники достовірні порівняно з контрольною групою; *夫 - показники достовірні порівняно з етаноловим фріброзом; \# - показники достовірні порівняно з ВЕ тваринами.

Таблиця 2 - Зміни показників пероксидного окиснення ліпідів у сироватці крові

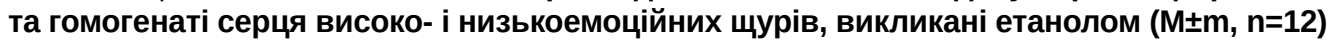

\begin{tabular}{|c|c|c|c|c|}
\hline \multirow{3}{*}{ Група } & \multicolumn{4}{|c|}{ "Показник } \\
\hline & \multicolumn{2}{|c|}{ ШО } & \multicolumn{2}{|c|}{ ТБК-ап } \\
\hline & $\begin{array}{c}\text { сироватка крові, } \\
\text { ум. од. } \text { мл }^{-1}\end{array}$ & $\begin{array}{c}\text { гомогенат серця, } \\
\text { ум. од. } \cdot^{-1}\end{array}$ & $\begin{array}{c}\text { сироватка крові, } \\
\text { ум. од. } \cdot \text { мл }^{-1}\end{array}$ & $\begin{array}{c}\text { гомогенат серця, } \\
\text { ум. од. } \cdot \Gamma^{-1}\end{array}$ \\
\hline \multicolumn{5}{|c|}{ ВЕ тварини } \\
\hline Контрольна & $2,514 \pm 0,021$ & $2,716 \pm 0,036$ & $4,725 \pm 0,046$ & $3,667 \pm 0,036$ \\
\hline Етаноловий фріброз & $3,765 \pm 0,026^{*}$ & $3,848 \pm 0,029 *$ & $8,617 \pm 0,044^{*}$ & $7,900 \pm 0,064^{*}$ \\
\hline Етаноловий цироз & $4,885 \pm 0,013^{\star, \star \star}$ & $5,193 \pm 0,009^{\star, \star \star}$ & $9,150 \pm 0,094^{\star, \star \star}$ & $8,850 \pm 0,051^{\star, \star \star}$ \\
\hline \multicolumn{5}{|c|}{ НЕ тварини } \\
\hline Контрольна & $2,107 \pm 0,010^{\#}$ & $2,301 \pm 0,011^{\#}$ & $6,033 \pm 0,051^{\#}$ & $4,750 \pm 0,034^{\#}$ \\
\hline Етаноловий фріброз & $3,412 \pm 0,050^{*, \#}$ & $3,645 \pm 0,047^{*, \#}$ & $8,317 \pm 0,051^{*, \#}$ & $7,667 \pm 0,047^{*, \#}$ \\
\hline Етаноловий цироз & $4,678 \pm 0,046^{*, \#, \star \star}$ & $5,023 \pm 0,021^{*, \#, \star \star}$ & $8,958 \pm 0,091^{\star, \star \star}$ & $8,150 \pm 0,080^{*, \#, \star \star}$ \\
\hline
\end{tabular}

$(p<0,001)$, ТБК-ап - на 93,7 \% (p<0,001) й у 2,4 раза (p<0,001), ШО - на 94,3\% $\%(p<0,001)$ та 91,2 \% (р<0,001). У НЕ тварин підвищення показників було таким: ДК - на 50,0 \% $(p<0,001)$ i $52,7 \%(p<0,001)$, TK - на 54,2\% (p<0,001) та $55,0 \%(p<0,001)$, ТБК-ап - на 48,5\% $(p<0,001)$ i $71,6 \%(p<0,001)$, ШО сир та ШО гом - у 2,2 раза $(p<0,001)$. Як і при ЕФ, показники ДК, ТК, ТБК-ап та ШО зросли більше і були достовірно вищими у ВЕ щурів порівняно з НЕ. Порівнюючи результати при ЕФ та ЕЦ, слід відзначити достовірне збільшення у сироватці крові та гомогенаті серця значень ДК, ТК, ТБК-ап при цирозі печінки. Отримані результати свідчать про більше ураження організму ВЕ тварин, яке наростало 3 тяжкістю патології.

У К у ВЕ щурів показники ОМП ${ }_{370}$ і ОМП були значно більшими у сироватці крові (у 2,4 раза, $p<0,001$; на 64,3 \%, p<0,001) і меншими - В гомогенаті серця (на $70 \%$, р<0,001; на 63,4 \%, p<0,001) (табл. 3). При ЕФ відмічено їх зростання в усіх групах (крім ОМП ${ }_{370}$ у сироватці крові ВЕ тварин). Так, у ВЕ щурів значення ОМП у сироватці крові й гомогенаті серця збільшилося, відповідно, на 2,3\% (p>0,05) й у 3,4 раза $(p<0,001)$, у HE - у 2,4 раза $(p<0,001)$ і на 27,2\% (p<0,001). Причому тільки в гомогенаті серця ВЕ тварин показник ОМП ${ }_{370}$ був вищим. Значення ОМП ${ }_{430} \mathrm{y}$ сироватці крові й гомогенаті серця збільшилося: у ВЕ щурів - відповідно, на 50,5 \% (p<0,001) й у $4,3$ раза ( $<<0,001)$, у НЕ - у 2,5 раза $(p<0,001)$. При ЕЦ, порівняно з К, відмічено зменшення показника ОМП ${ }_{370}$ у сироватці крові ВЕ тварин на 34,3\% ( $p<0,001)$. У всіх решта щурів він збільшився. Так, у гомогенаті серця ВЕ щурів значен-

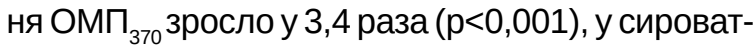
ці крові та гомогенаті серця НЕ тварин - на $74,5 \%(p<0,001)$ і 89,6 \% ( $<<0,001)$. Показник $\mathrm{OMП}_{430}$ у сироватці крові та гомогенаті серця підвищився: у ВЕ щурів - відповідно, на $57 \%$ $(p<0,001)$ й у 4,3 раза $(p<0,001)$, у НЕ - y 2,2 раза $(p<0,001)$ і 2,5 раза ( $<<0,001)$. Причому тільки у сироватці крові ВЕ тварин він був більшим. При ЕЦ, порівняно з ЕФ, показник ОМП ці крові був нижчим у ВЕ і НЕ щурів, а в гомогенаті серця - вищим у НЕ тварин. Значення $\mathrm{OMП}_{430}$ при ЕЦ, порівняно з ЕФ, було меншим у сироватці крові НЕ щурів. Отже, і ЕФ, і ЕЦ супроводжувалися зростанням вмісту ОМП, що значно не залежало від емоційного стану тварин. 
Таблиця 3 - Зміни показників пероксидного окиснення ліпідів у сироватці крові та гомогенаті

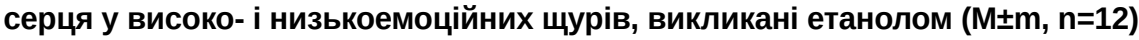

\begin{tabular}{|c|c|c|c|c|}
\hline \multirow{3}{*}{ Група } & \multicolumn{4}{|c|}{ Показник } \\
\hline & \multicolumn{2}{|c|}{ ОМП $_{370}$, ммоль/г протеїну } & \multicolumn{2}{|c|}{ ОМП $_{430}$, ммоль/г протеїну } \\
\hline & сироватка крові & гомогенат серця & сироватка крові & гомогенат серця \\
\hline \multicolumn{5}{|c|}{ ВЕ тварини } \\
\hline Контрольна & $0,282 \pm 0,005$ & $0,159 \pm 0,004$ & $0,365 \pm 0,007$ & $0,167 \pm 0,003$ \\
\hline Етаноловий фріброз & $0,289 \pm 0,005$ & $0,542 \pm 0,011^{*}$ & $0,549 \pm 0,010^{\star}$ & $0,712 \pm 0,014^{\star}$ \\
\hline Етаноловий цироз & $0,210 \pm 0,004^{\star, \star \star}$ & $0,538 \pm 0,009 *$ & $0,573 \pm 0,024^{*}$ & $0,715 \pm 0,014^{*}$ \\
\hline \multicolumn{5}{|c|}{ НЕ тварини } \\
\hline Контрольна & $0,117 \pm 0,001^{\#}$ & $0,271 \pm 0,012^{\#}$ & $0,222 \pm 0,002^{\#}$ & $0,274 \pm 0,012^{\#}$ \\
\hline Етаноловий фріброз & $0,285 \pm 0,005^{*}$ & $0,344 \pm 0,003^{*, \#}$ & $0,548 \pm 0,012^{*}$ & $0,696 \pm 0,012^{*}$ \\
\hline Етаноловий цироз & $0,205 \pm 0,003^{\star, \star \star}$ & $0,513 \pm 0,009^{\star, \star \star}$ & $0,498 \pm 0,012^{\star, \#, \star \star}$ & $0,687 \pm 0,012^{*}$ \\
\hline
\end{tabular}

У К активність СОД вищою в НЕ тварин, відповідно, на $69,9 \%$ $(p<0,001)$ та 69,5\% (p<0,001). При ЕФ, порівняно з К, вона була більшою у сироватці крові й гомогенаті серця ВЕ щурів, відповідно, у 2,5 раза $(p<0,001)$ і 2,5 раза $(p<0,001)$, в HE - на $81,4 \%$ $(p<0,001)$ та $77,7 \%(p<0,001)$, залишаючись при цьому значно вищою в НЕ тварин. При ЕЦ, порівняно з К, активність СОД зросла у сироватці крові й гомогенаті серця ВЕ тварин, відповідно, у 3,6 раза $(p<0,001)$ i 5,1 раза ( $p<0,001)$, у HE - y 2,1 раза $(p<0,001)$ та 2,8 раза $(p<0,001)$ і була вищою в гомогенаті серця ВЕ щурів. При ЕЦ, порівняно з ЕФ, вона була більшою. Очевидно, зростання активності СОД перешкоджає значній активації ПОЛ.
Активність Кат (табл. 4) у сироватці крові контрольних щурів була вищою в НЕ тварин у 2,5 раза $(p<0,001)$. При ЕФ спостерігали ії зростання у сироватці крові й гомогенаті серця ВЕ щурів, відповідно, в 5,7 раза $(p<0,001)$ i 3,9 раза $(p<0,001)$, у HE - у 2 рази $(p<0,001)$ та 2,9 раза $(p<0,001)$, причому показник був значно вищим у ВЕ тварин. При ЕЦ відзначали збільшення активності Кат у сироватці крові й гомогенаті серця ВЕ щурів, відповідно, в 7,2 раза $(p<0,001)$ i 5,7 раза $(p<0,001)$, у HE - у 2,8 раза $(p<0,001)$ та 5,1 раза $(p<0,001)$, і вона не залежала від емоційності. Слід відмітити, що при ЕЦ активність Кат була вищою порівняно з такою при ЕФ.

Вміст ЦП (табл. 5) у сироватці крові ВЕ тварин був більшим на 18,3 \% (p<0,001). При ЕФ та

Таблиця 4 - Зміни активності антиоксидантної системи у сироватці крові та гомогенаті серця

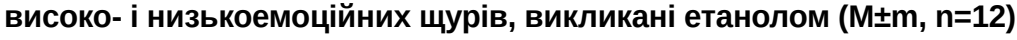

\begin{tabular}{|c|c|c|c|c|}
\hline \multirow{3}{*}{ Група } & \multicolumn{4}{|c|}{ "Показник } \\
\hline & \multicolumn{2}{|c|}{ СОД } & \multicolumn{2}{|c|}{ Кат } \\
\hline & $\begin{array}{c}\text { сироватка крові, } \\
\text { пит. од./мл }\end{array}$ & $\begin{array}{c}\text { гомогенат серця, } \\
\text { пит. од./г }\end{array}$ & $\begin{array}{c}\text { сироватка крові, } \\
\text { мкат/л }\end{array}$ & $\begin{array}{c}\text { гомогенат серця } \\
\text { мкат/кг }\end{array}$ \\
\hline \multicolumn{5}{|c|}{ ВЕ тварини } \\
\hline Контрольна & $0,207 \pm 0,001$ & $0,149 \pm 0,007$ & $0,107 \pm 0,001$ & $0,163 \pm 0,006$ \\
\hline Етаноловий фріброз & $0,515 \pm 0,003^{*}$ & $0,382 \pm 0,003^{*}$ & $0,615 \pm 0,003^{*}$ & $0,640 \pm 0,007^{*}$ \\
\hline Етаноловий цироз & $0,738 \pm 0,010^{\star, \star \star}$ & $0,762 \pm 0,010^{\star, \star \star}$ & $0,772 \pm 0,026^{\star, \star \star}$ & $0,932 \pm 0,014^{\star, \star \star}$ \\
\hline \multicolumn{5}{|c|}{ HЕ тварини } \\
\hline Контрольна & $0,352 \pm 0,007^{\#}$ & $0,252 \pm 0,006^{\#}$ & $0,269 \pm 0,005^{\#}$ & $0,179 \pm 0,007$ \\
\hline Етаноловий фріброз & $0,639 \pm 0,008^{*, \#}$ & $0,448 \pm 0,006^{*, \#}$ & $0,539 \pm 0,012^{*, \#}$ & $0,526 \pm 0,003^{*, \#}$ \\
\hline Етаноловий цироз & $0,734 \pm 0,012^{\star, \star \star}$ & $0,712 \pm 0,012^{\star, \#, \star \star}$ & $0,759 \pm 0,030^{\star, \star \star}$ & $0,921 \pm 0,009^{\star, \star \star}$ \\
\hline
\end{tabular}

Таблиця 5 - Зміни показників антиоксидантної системи у сироватці крові високо- і низькоемоційних щурів, викликані етанолом ( $\pm m, n=12)$

\begin{tabular}{|c|c|c|}
\hline \multirow{2}{*}{ Група } & \multicolumn{2}{|c|}{ ППоказник } \\
\hline & ЦП, мкат/л & ПАК, пит. од./Мл \\
\hline \multicolumn{3}{|c|}{ ВЕ тварини } \\
\hline Контрольна & $3,767 \pm 0,040$ & $0,534 \pm 0,011$ \\
\hline Етаноловий фріброз & $6,508 \pm 0,067^{*}$ & $0,926 \pm 0,011^{*}$ \\
\hline Етаноловий цироз & $6,397 \pm 0,110^{*}$ & $1,870 \pm 0,024^{\star, \star \star}$ \\
\hline \multicolumn{3}{|c|}{ НЕ тварини } \\
\hline Контрольна & $2,208 \pm 0,020^{\#}$ & $0,772 \pm 0,026^{\#}$ \\
\hline Етаноловий фріброз & $5,398 \pm 0,026^{*, \#}$ & $0,916 \pm 0,007^{*}$ \\
\hline Етаноловий цироз & $6,700 \pm 0,144^{\star, \star \star}$ & $1,750 \pm 0,042^{\star, \#, \star \star}$ \\
\hline
\end{tabular}


ЕЦ він підвищився: у ВЕ щурів - на 72,8 \% $(p<0,001)$ і $69,8 \%(p<0,001)$, у HE - у 2,5 раза $(p<0,001)$ і 3 рази $(p<0,001)$ відповідно. Причому різниці в показниках при ЕФ і ЕЦ у ВЕ щурів не спостерігали, а в НЕ тварин вони були більшими при ЕЦ. При ЕФ вміст ЦП залишався вищим у BE щурів.

Пероксидазна активність крові в К була на $44,5 \%$ ( $<<0,001)$ вищою в НЕ щурів. При ЕФ, порівняно з К, вона зросла: у ВЕ тварин - на $73,2 \%(p<0,001)$, у НЕ - на 18,6 \% (p<0,001). При ЕЦ, порівняно з К, підвищилась: у ВЕ щурів - у 3,5 раза $(p<0,001)$, в HE - у 2,3 раза $(p<0,001)$, у ВЕ тварин була вищою на 6,9% (p<0,05). Отже,

\section{СПИСОК ЛІТЕРАТУРИ}

1. Mellinger J. L. Epidemiology of alcohol use and alcoholic liver disease / J. L. Mellinger // Clinical Liver disease. - 2019. - No. 13 (5). - P. 136-139.

2. Mathurin $P$. Trends in the management and burden of alcoholic liver disease / P. Mathurin, R. Bataller // J. Hepatol. - 2015. - No. 62. - P. S38-S46.

3. Cardiac manifestations in alcoholic liver disease / S. Milić, D. Lulić, D. Štimac [et al.] // BMJ Journal. 2016. - Access mode : https://pmj.bmj.com/content/92/ $1086 / 235$

4. Ismaiel A. Cardiovascular risk in fatty liver disease: The liver-heart axis -literature review / A. Ismaiel, D. L. Dumitraşcu // Front. Med (Lausanne). - 2019. No. 6. - P. 202.

5. Is NAFLD an independent risk factor for increased IMT in T2DM? / E. Cakir, M. Ozbek, N. Colak [et al.] // Minerva Endocrinol. - 2012. - No. 37. - P. 187-193.

6. Marc De Hert Marc De Hert, Johan Detraux, Davy Vancampfort // Dialogues Clin. Neurosci. - 2018. 20 (1). - P. 31-40.

7. Говоруха О. Ю. Значення взаємодії перекисного окиснення ліпідів і антиоксидантних систем в розвитку патологічних процесів / О. Ю. Говоруха, О. Ю. Шнайдерман // Експерим. і клініч. медицина. 2016. - № 4 (73). - С. 10-14.

8. Пат. 135949 Україна, МПК G 09 В 23/28. Спосіб моделювання етанолового фріброзу у високоемоційних та низькоемоційних щурів-самців / Костюк О. А., Денефіль О. В., Головата Т. К. - Опубл. 25.07.19, Бюл. 14/2019.

9. Пат. 135948, МПК G 09 В 23/28. Спосіб моделювання етанолового цирозу у високоемоційних та низькоемоційних щурів-самців / Костюк О. А., Денефіль О. В., Головата Т. К. - Опубл. 25.07.19, Бюл. 14/2019.

\section{REFERENCES}

1. Mellinger, J.L. (2019). Epidemiology of alcohol use and alcoholic liver disease. Clinical Liver Disease, 13 (5), 136-139. при ЕЦ ПАК була більшою порівняно з такою при ЕФ.

Отже, етанолові фріброз і цироз печінки викликають інтенсифрікацію процесів ПОЛ з одночасною активацією антиоксидантної системи у сироватці крові й гомогенаті серця щурів з різною емоційністю. Інтенсифрікація ПОЛ вираженіша у ВЕ тварин більше при ЕЦ.

ВИСНОВКИ. Етанолові фріброз і цироз печінки у щурів викликають ушкодження організму за оксидаційним механізмом. Інтенсифрікація ПОЛ більш виражена при цирозі у сироватці крові та гомогенаті серця високоемоційних тварин.

10. Лукьянова Л. В. Изучение поведенческих реакций при введении косреина, карбмазепина и их композиций в условиях формалинового отека у крыс / Л. В. Лукьянова // Укр. біофрармац. журн. - 2016. - 42, № 1. - C. 22-26. ISSN 2311-715X.

11. Чевари С. Роль супероксиддисмутазы в окислительных процессах клетки и метод определения ее в биологических материалах / С. Чевари, И. Чаба, Й. Секей // Лаб. дело. - 1985. - № 11. - С. 678-681.

12. Метод определения активности каталазы / М. А. Королюк, Л. И. Иванова, И. Г. Майорова, В. Е. Токарев // Лаб. дело. - 1988. - № 1. - С. 16-19.

13. Гаврилов В. Б. Спектрофотометрическое определение содержания гидроперекисей липидов в плазме крови / В. Б. Гаврилов, М. И. Мишкорудная // Лаб. дело. - 1983. - № 3. - С. 33-35.

14. Коробейникова Э. Н. Модисрикация определения продуктов ПОЛ в реакции с тиобарбитуровой кислотой / Э. Н. Коробейникова // Лаб. дело. - 1989. № 7. - C. 8-10.

15. Доклінічні дослідження лікарських засобів : метод. рек. / за ред. О. В. Стесранова. - К. : Авіцена, 2001. $-528 \mathrm{c}$.

16. Мещишен І. Ф. Метод визначення окислювальної модифікації білків плазми крові / І. Ф. Мещишен // Буковин. мед. вісн. - 1998. - 2, № 1. - С. 156-158.

17. Клінічна лабораторна діагностика: нормативні, директивні, правові документи / гол. ред. В. М. Заболотько. - К. : МВЦ “Медінформ”, 2003. - 856 с.

18. Попов Т. Метод определения пероксидазной активности крови / Т. Попов, Л. Нейковська // Гигиена и санитария. - 1971. - № 10. - С. 89-93.

19. Лапач С. Н. Статистические методы в медико-биологических исследованиях с использованием Excel / С. Н. Лапач, А. В. Чубенко, П. Н. Бабич - К. : Морион, 2000. - 320 c

2. Mathurin, P., \& Bataller, R. (2015), Trends in the management and burden of alcoholic liver disease. $J$. Hepatol., 62, S38-S46. 
3. Milić, S., Lulić, D., Štimac, D., Ružić, A., \& Zaputović, L. (2016). Cardiac manifestations in alcoholic liver disease. BMJ Journal. Retrieved from: https://pmj. bmj.com/content/92/1086/235.

4. Ismaiel, A. \& Dumitraşcu, D.L. (2019). Cardiovascular risk in fatty liver disease: The liver-heart axis literature review. Front. Med. (Lausanne), 6, 202.

5. Cakir. E., Ozbek, M., Colak, N., Cakal, E., \& Delibaşi, T. (2012). Is NAFLD an independent risk factor for increased IMT in T2DM? Minerva Endocrinol., 37, 187-193.

6. Marc De Hert, Johan Detraux, \& Davy Vancampfort (2018). Dialogues Clin. Neurosci., 20 (1), 31-40.

7. Hovorukha, O.Yu. \& Shnajderman, O.Yu. (2016). Znachennia vzaiemodii perekysnoho okysnennia lipidiv i antyoksydantnykh system v rozvytku patolohichnykh protsesiv [Significance of the interaction of peroxide oxidation of lipids and antioxidant systems in the development of pathological processes]. Eksperymentalna i klinichna medytsyna - Experimental and Clinical Medicine, 4 (73), 10-14 [in Ukrainian].

8. Kostyuk, O.A., Denefil, O.V., \& Holovata, T.K. (2019). Patent № 135949 IPC: G 09 B 23/28; Sposib modeliuvannia etanolovoho fibrozu u vysokoemotsiinykh ta nyzkoemotsiinykh shchuriv-samtsiv [Method of modeling ethanol fibrosis in highly emotional and low-emotional male rats]. Published on July 25, 2019, Bull. 14/2019. [in Ukrainian].

9. Kostyuk, O.A., Denefil, O.V. \& Holovata, T.K. (2019). Patent № 135948 IPC: G 09 B 23/28; Sposib modeliuvannia etanolovoho tsyrozu u vysokoemotsiinykh ta nyzkoemotsiinykh shchuriv-samtsiv [Method of modeling ethanol cirrhosis in highly emotional and low-emotional male rats]. Published on July 25, 2019, Bull. 14/2019 [in Ukrainian].

10. Lukyanova, L.V. (2016). Izuchenie povedenchiskikh reaktsiy pri vvedenii kofeina, karbamazepina i ikh kompozitsiy v usloviyakh formalinovogo oteka u krys [Study of behavioral reactions with the introduction of caffeine, carbmazepine and their compositions under conditions of formalin edema in rats]. Ukrainskyi biopharmatsevtychnyi zhurnal - Ukrainian Biopharmaceutical Journal, 42 (1), 22-26 [in Russian].

11. Chevari, S., Chaba, I. \& Sekei, I. (1985). Rol superoksiddismutazy $v$ okislitelnykh protsessakh kletki i metod opredeleniya ego $v$ biologicheskikh materialakh [The role of superoxide dismutase in the oxidative processes of the cell and the method for its determination in biological materials]. Laboratornoye delo - Laboratoty Work, 11, 678-681 [in Russian].

12. Korolyuk, M.A. , Ivanova, L.I., Majorova, I.G., \& Tokarev V. E. (1988). Metod opredelenija aktivnosti katalazy [Method for determination of catalase activity]. Laboratornoye delo - Laboratoty Work, 1, 16-19 [in Russian].

13. Gavrilov, V.B. \& Mishkorudnaya, M.I. (1983). Spectrofotometricheskoe opredelenie soderzhaniya gidroperekisey lipidov v plazme krovi [Spectrophotometric determination of the content of lipid hydroperoxides in blood plasma]. Laboratornoye delo-Laboratoty Work, 3, 33-35 [in Russian].

14. Koobejnikova, EN. (1989). Modifikatsiya opredeleniya produktov $\mathrm{POL} v$ reaktsiyi s tiobarbiturovoy kislotoy [Modification of the determination of LPO products in the reaction with thiobarbituric acid]. Laboratornoye delo - Laboratoty Work, 7, 8-10 [in Russian].

15. Stefanov, O.V. (Ed.). (2001). Doklinichni doslidzhennia likarskykh zasobiv: metodychni rekomendatsii [Preclinical studies of medications: guidelines]. Kyiv: Avitsenna [in Ukrainian].

16. Meshchyshynm, I.F. (1998). Metod vyznzchennia okysliuvalnoi modyfikatsii bilkiv plazmy krovi [The method of determining oxidative modification of blood plasma proteins]. Bukovynskyi medychnyi visnyk - Bukovinian Medical Herald, 2 (1), 156-158 [in Ukrainian].

17. (2003). Klinichna ta laboratorna diahnostyka. Normatyvni dyrektyvni pravovi dokumenty [Clinical and laboratory diagnostics. Normative directive legal documents]. Kyiv: MVTS "Medinform" [in Ukrainian].

18. Popov, T. \& Neykovska, L. (1971). Metod opredileniya peroksidaznoy aktivnosti krovi [Method for determination of blood peroxidase activity]. Gigiyena $i$ sanitariya - Hygiene and Sanitation, 10, 89-93 [in Russian].

19. Lapach, S.N., Chubenko, A.V. \& Babich, P,N. (2000). Statisticheskie metody $v$ mediko-biologicheskikh issledovaniyah s ispolzovaniem Excel [Statistical methods in biomedical research using Excel]. Kyiv: Morion [in Russian].

О. А. Костюк, О. В. Денесииль

ТЕРНОПОЛЬСКИЙ НАЦИОНАЛЬНЫЙ МЕДИЦИНСКИЙ УНИВЕРСИТЕТ ИМЕНИ И. Я. ГОРБАЧЕВСКОГО МОЗ УКРАИНЫ

\section{РОЛЬ БИОХИМИЧЕСКИХ НАРУШЕНИЙ В РАЗВИТИИ ЭТАНОЛОВЫХ ФИБРОЗА И ЦИРРОЗА ПЕЧЕНИ У ВЫСОКО- И НИЗКОЭМОЦИОНАЛЬНЫХ КРЫС}

\section{Резюме}

Вступление. Чрезмерное употребление алкоголя является распространенным социальным бедствием, что вызывает необратимые изменения в организме.

Цель исследования - оценить состояние про- и антиоксидантной системы в крови и гомогенате сердца высоко- и низкоэмоциональных (ВЭ, НЭ) крыс-самцов при этаноловых фриброзе и циррозе печени.

Методы исследования. Опыты выполнены на 96 ВЭ и НЭ беспородных крысах-самцах в возрасте 5,5-6 месяцев. Животных разделили на З группы: контрольная (К); этаноловый фриброз (ЭФ); этаноловый цирроз печени (ЭЦ). Эмоциональность определяли по методике “открытое поле”. В сыворотке крови (сыв) и гомогенате сердца (гом) определяли активность супероксиддисмутазы (СОД), каталазы (Кат), 
содержание диеновых (ДК), триенових (ТК) конъюгатов, шиффровых оснований (ШО), ТБК-активных продуктов (ТБК-ап), в сыворотке крови - пероксидазную активность крови (ПАК), содержание церулоплазмина (ЦП).

Результаты и обсуждение. В К у ВЭ животных, по сравнению с НЭ, было меньше содержание ДК, ТК, ТБК-ап, больше - содержание ШО. При ЭФ и ЭЦ все показатели у ВЭ и НЭ крыс возросли и были выше у ВЭ животных. В К у ВЭ крыс ОМП возросли (кроме ОМП с ЭФ, ОМП с ЭФ, ОМП возросла, больше у ВЭ животных, но оставалась выше у НЭ крыс. При ЭЦ возросла больше у ВЭ животных и была выше в гом. При ЭЦ, по сравнению с ЭФ, активность СОД была больше. Активность Кат в сыв в К была выше у НЭ крыс. При ЭФ она увеличилась и была выше у ВЭ животных. При ЭЦ возрастала в большей степени у ВЭ крыс и не зависела от эмоциональности. При ЭЦ, по сравнению с ЭФ, активность Кат была больше. Содержание ЦП в сыв было выше у ВЭ животных. При ЭФ и ЭЦ оно возросло, больше у НЭ крыс. Разницы в содержании ЦП при ЭФ и ЭЦ у ВЭ животных не наблюдали, у НЭ крыс более высокие значения отмечали при ЭЦ. При ЭФ у ВЭ животных содержание ЦП оставалось большим. В К ПАК была выше у НЭ крыс; возросла при ЭФ и ЭЦ (в большей степени). При ЭЦ ПАК была выше у ВЭ животных.

Выводы. Этаноловые фриброз и цирроз печени у крыс вызывают повреждение организма по оксидационному механизму. Интенсификация Пол больше выражена при циррозе в сыворотке крови и гомогенате сердца высокоэмоциональных животных.

КЛЮЧЕВЫЕ СЛОВА: этанол; фиброз печени; цирроз печени; высоко- и низкоэмоциональные крысы-самцы; кровь; серце.

O. A. Kostiuk, O. V. Denefil

I. HORBACHEVSKY TERNOPIL NATIONAL MEDICAL UNIVERSITY

\section{THE ROLE OF BIOCHEMICAL DISORDERS IN THE DEVELOPMENT OF ETHANOL FIBROSIS AND CIRRHOSIS OF THE LIVER IN HIGH AND LOW EMOTIONAL RATS}

\section{Summary}

Introduction. Excessive alcohol consumption is one of the most common social illness, causing irreversible changes in the body.

The aim of the study - to evaluate the state of the pro- and antioxidant system in the blood and heart of highand low-emotional male rats (HE, LE) in ethanol fibrosis and cirrhosis of liver.

Research Methods. The experiments were performed on $96 \mathrm{HE}$ and LE outbred rats aged 5.5-6 months. Animals were divided into three groups - control (C), ethanol fibrosis (EF) and ethanol cirrhosis of the liver (EC). Emotionality was determined in the "open field". In blood serum (ser) and heart homogenate (hom) superoxide dismutase (SOD), catalase (Cat) activity, content of diene (DC), triene (TC) conjugates, shiff bases (SB), TBA-active products (TBA) in the blood - peroxidase activity $(P A)$, the content of ceruloplazmin (CP) were determined.

Results and Discussion. In $C$ in HE, in comparion with $L E$, there were smaller DC, TC, TBA, bigger SB. At $E F$ and $E C$, all indexes in $\mathrm{HE}$ and $L E$ increased and were higher in $\mathrm{HE}$. In $\mathrm{C}$ in $\mathrm{HEOMP}{ }_{370}$ and $O M P_{430}$ were bigger in ser, smaller in gom. At EF and EC they increased (except for $O M P_{370}$ in $\mathrm{HE}$ ser). In ser in $\mathrm{HE} \mathrm{OMP}_{370}$ were larger. In EC, compared with $E F, O M P_{370}$ in ser were smaller in $\mathrm{HE}$ and $L E$, and in gom - larger in $L E . O M P_{430}$ at $E C$, in comparison with EF, were smaller in ser LE. In C SOD is higher in LE. At EF SOD increased, more in HE, but remained higher in LE. At EC SOD increased more in HE and was higher at them in gom. At EC, in comparison with $E F$, SOD was bigger. Cat in ser in C was higher in LE. At EF Cat increased and was higher in HE. At EC Cat increased to a greater extent in HE and did not depend on emotionality. At EC, in comparison with EF, Cat was bigger. The $C P$ in ser was higher in HE. At EF and EC it increased, more at $L E$. There was no difference between CP in EF and $E C$ in HE rats; in LE there were greater values in EC. At EF in HE the content of CP remained higher. PA in $C$ was higher in LE; increased in EF and EC (more). At EC it was higher in HE.

Conclusions. Ethanol fibrosis and cirrhosis of the liver in rats causes damage of the body by an oxidative mechanism. Intensification of LPO is more pronounced in cirrhosis in the serum and heart homogenate of highly emotional animals.

KEY WORDS: ethanol; liver fibrosis; liver cirrhosis; high- and low-emotional male rats; blood; heart.

Отримано 09.11.20

Адреса для листування: О. В. Денесріль, Тернопільський національний медичний університет імені І. Я. Горбачевського мОз України, майдан Волі, 1, Тернопіль, 46001, Україна, e-mail: denefil@tdmu.edu.ua. 